\title{
The Role of Identity in the 2015 Romanian Shepherd Protests
}

Shepherds have a special place in the history and culture of Romania. For centuries they have had rights to graze their sheep in public pastures and manage them using traditional methods. Recent changes at the national and European level have presented a threat to this way of life and provoked protest gatherings in Bucharest. The most recent of these saw 3000 shepherds gather in December 2015 and charge the parliament buildings, leading to a stand-off with riot police, over plans to limit sheepdog numbers and restrict winter grazing rights. This paper examines the nature of the perceived challenges to the shepherd's way of life and how they have responded. The aims of the paper are to (1) place the shepherd protests in the context of post-communist mobilisations in Romania, and (2) consider the ways in which competing cultural and environmental claims are presented and managed in the valuing of the shepherd identity that remains rooted in traditional rural practices.

Keywords: shepherds, protest, Romania, hunting, identity, transhumance

\section{Introduction}

In December 2015 over 3000 shepherds from across Romania descended on Bucharest and staged noisy protests. Dressed in traditional shepherd outfits they demanded that recently introduced regulations limiting numbers of livestock protection dogs and restricting winter grazing rights be rescinded. The protests resulted in clashes and a standoff with riot police as the shepherds entered the grounds of Parliament (AFP, 2015). Following the protests the government agreed to temporarily suspend the introduction of the law and seek further consultation (Associated Press, 2015). The ability and willingness of shepherds to organise and stage a protest in this manner raises questions regarding issues of identity and mobilising capacity within a group consisting of largely marginalised and dispersed rural actors. In an environment where mechanisms for accountability are lacking and governance is weak, direct 
This is an Accepted Manuscript of an article published by Taylor \& Francis in Identities on 31 January 2018, available online:

https://www.tandfonline.com/doi/abs/10.1080/1070289X.2017.1400322

action can provide a venue for the presentation of collective claims.

Shepherds occupy a complicated position in contemporary Romanian society. As agricultural workers they are generally regarded as low-status in terms of occupational prestige (see Buzea and Scâneri, 2011), part of a marginalised rural environment. They have suffered from changes to land policies following the end of the communist regime, as fragmentation of rural landholdings has limited their ability to continue traditional transhumant ${ }^{1}$ practices in managing their livestock (Huband et al, 2010). Additionally, the increased attention given to the conservation of large carnivores (such as bear, lynx and wolves) (Salvatori et al, 2002) has introduced new challenges in ensuring the protection of their livestock. In spite of these difficulties, the shepherd continues to occupy a place in Romanian culture, with stories regarding the shepherd abounding, including in the form of foundational myths (Juler, 2014). This means that although the shepherd is an increasingly economically and socially marginal figure, the identity of the shepherd continues to carry a degree of influence in society.

This paper considers the mobilisation of December 2015 in light of the shepherd's position in Romanian society. The aims of the paper are to (1) place the shepherd protests in the context of post-communist mobilisations in Romania, and (2) consider the ways in which competing cultural and environmental claims are presented and managed in the valuing of the shepherd

\footnotetext{
1 Quoting the Romanian Minister of Agriculture, Constantin (2004: 93) identifies transhumance as "An extensive system of production, economically efficient, and practiced by herders who own livestock of 5002000 heads. In the past, some herders owned over 20,000 heads. Transhumance is the movement of ovine herds, followed by a few mules, goats, horses, and cows, which travel in summer to highland pastures, and in winter to lowland regions, meadows, and pastures, placed often hundreds of kilometers away. It appeared and developed as an economic necessity for those herders who lack sufficient fodder resources in their native regions in order to breed and exploit the ovine livestock."
} 
This is an Accepted Manuscript of an article published by Taylor \& Francis in Identities on 31 January 2018, available online:

https://www.tandfonline.com/doi/abs/10.1080/1070289X.2017.1400322

identity that remains rooted in traditional rural practices. The analysis contributes to understandings of the way rural identities are presented in post-communist societies. The article is divided into five sections. The first section examines the literature on protest mobilisations and sets the context of previous significant events in Romania. The second section considers the role of the shepherd in Romania, outlining the nature of their transhumant migration practices and how these have been impacted by the changes since 1989. The methodology used to analyse the protest mobilisation is outlined in the third section. The 2015 protests are examined in the fourth section, outlining the unfolding events and the government response.. Finally, the paper examines the shepherd perspective and the extent to which identity served as a mobilising force.

\section{Contentious Politics and the Role of Identity}

The decision to engage in protest brings costs, so the strength of the perceived injustice or threat is key in mobilising actors. Tilly and Tarrow (2007: 58) argue that 'most people who engage in contentious politics see themselves as responding to threats they perceive to their interests, their values, or their identities.' Protest often results from the failure or absence of established, institutionalised forms of participation, as the presentation of a particular claim resides at the centre of the action (Tarrow, 2011). Where representational institutions are weak or access restricted, direct action may be the only viable option. Although protest actions can be seen as reactive, they also aim to present alternative visions of what is possible, contesting the dominant or accepted interpretation. The state serves as the key target of claim-making as it defines the legal and political structure within which civil society is permitted to operate and possesses the power to vary rights and obligations of individuals and groups (Chandhoke, 2001). 
This is an Accepted Manuscript of an article published by Taylor \& Francis in Identities on 31 January 2018, available online:

\section{https://www.tandfonline.com/doi/abs/10.1080/1070289X.2017.1400322}

Success or otherwise of a protest action will be determined by internal and external factors.

Where a group or individual perceives conditions to be favourable with a higher likelihood their message will resonate they will be more confident in engaging in contentious actions. Tilly (2008: 92) summarises the opportunities and threats around contentious action in five broad categories- openness of the regime, elite coherence, stability of political alignments, availability of allies, and repression/facilitation. Each category is dynamic, meaning the character of opportunities needs to be monitored and interpreted by actors to maximise chances of success. Presentation of opportunities and threats in this form can risk overstating the extent to which actors can recognise the nature of the environment. Failure may result where the external environment is misrecognised. The emergence or increased intensity of perceived threats can also serve to motivate and mobilise contentious behaviour (Goldstone and Tilly, 2001). When considering contentious actions it is therefore essential to consider how changes in the external environment are perceived by those impacted.

Engaging in disruptive actions such as protest ultimately seeks to achieve a particular goal, in which the claims of those involved are resolved. The degree of space available for opposition to emerge is crucial in determining the forms of action that will be seen as transgressive and also point to the distance between formally acceptable behaviours. The ability and willingness of the state to punish certain behaviours is an important factor in shaping their salience and effectiveness. Free spaces provide the opportunity for individuals and groups within society to contest the state's presentation of the boundaries of acceptable behaviour (Johnston, 2011). In democratic states the space of tolerated protest actions is broader and governed by rules and regulations that reflect dominant social norms (Tilly and Wood, 2009). Each state has a zone of prescribed behaviour that is determined by the degree of democracy and the capacity to enforce its will (Tilly, 2003). In the absence of an obvious target or ability 
This is an Accepted Manuscript of an article published by Taylor \& Francis in Identities on 31 January 2018, available online:

\section{https://www.tandfonline.com/doi/abs/10.1080/1070289X.2017.1400322}

to shake the established narrative, a group or individual may turn to prescribed actions to force an opening.

Internal dynamics of groups engaged in protest are also important in determining the likelihood of success and their ability to maintain commitment. Resource dependence suggests that in order to sustain themselves groups 'must enter into transactions and relations with elements in the environment that can supply the required resources and services.' (Aldrich and Pfeffer, 1976: 83) These relationships constrain what is possible, but are necessary to ensure continued support. In the context of contentious actions this position links internal group dynamics with those represented by the opportunity structures. While protest actions seek to disrupt and challenge established practices (Tarrow, 2011), they also need to be calibrated in such a way as to not alienate potential supporters. Considering how contentious actors present themselves, Tilly and Wood (2009: 4) refer to displays of worthiness, unity, numbers and commitment (WUNC). Contentious actors that are able to display WUNC are more able to demonstrate the legitimacy of their actions in the face of counterclaims and increase the chances of success.

Shared identities provide a basis on which actors generate commitment to a cause, mobilise members and generate external legitimacy. Defining the character of collective identity, Hunt and Benford (2004: 447) argue that:

it is a cultural representation, a set of shared meanings that are produced and reproduced, negotiated and renegotiated, in the interactions of individuals embedded in particular sociocultural contexts.

As such, collective identities are fluid, remaining latent, activating in response to perceived threats to recognisable interests (Klandermans, 2004; see also Buechler and Buechler, 2000; 
This is an Accepted Manuscript of an article published by Taylor \& Francis in Identities on 31 January 2018, available online:

\section{https://www.tandfonline.com/doi/abs/10.1080/1070289X.2017.1400322}

Wald, 2013). Where internal shared beliefs and experiences are stronger and reinforce the sense of a collective good, the longevity and robustness of the action will be increased. Tarrow (2011: 31) argues that 'co-ordination of collective action depends on the trust and cooperation that are generated among participants by shared understandings and identities'. Forming a shared identity in this manner facilitates trust but also enables the 'activation of available us-them boundaries' (Tilly, 2003: 132; Hunt and Benford, 2004). These boundaries bind participants more closely together, but also pose the risk of alienating potential supporters if policed too rigidly. Therefore, groups engaged in contentious actions have to balance tensions between a strong unified core, while at the same time not closing off opportunities to attract allies and negotiate solutions.

\section{Shepherds in Romania}

Shepherds' traditions and customs are part of Romania's historical identity (Vuia, 1963), but Romanian shepherds have for several decades found themselves in conflict with modernity and capitalism (Constantin, 2004; Shirasaka, 2007). Historically, shepherds featured in Romanian folk culture, with Juler (2014: 5) noting that:

The country's most famous myth of origin, Mioriţa, tells the story of a good shepherd who lets himself be murdered by jealous rivals after being warned of their plan by a talking lamb... [and is] sometimes seen as a symbol of Christian martyrdom... turning the other cheek.

This story presents the shepherd as a foundational figure, embodying the idealised values of the nation. With the end of the communist regime occupational statuses changed and previously valued professions and locations were re-evaluated, leading to social upheaval (Kideckel, 2004). Despite cultural significance, the social position of shepherds is regarded as quite low, in common with agricultural workers generally. This is reflected in a study of 
This is an Accepted Manuscript of an article published by Taylor \& Francis in Identities on 31 January 2018, available online:

https://www.tandfonline.com/doi/abs/10.1080/1070289X.2017.1400322

organisational prestige by Buzea and Scâneri (2011: 12) finds that shepherds are ranked $38^{\text {th }}$ out of the 40 professions considered. The shepherd is seen as linked to a past time that is less relevant in the contemporary world, something that has been reinforced by the maintenance of traditional practices.

An important aspect of shepherding in Romania historically has been the use of transhumant practices to access grazing. This is referred to as 'după coada oilor' or 'going on the road' and involves 'long-distance walks with their flocks between summer and winter pastures... [covering] anything from 50 to $300 \mathrm{~km}$ and periods of between two days and eight weeks.' (Juler, 2014: 1) This practice was common throughout the Carpathian mountain chain, but has declined in recent years. Huband et al (2010: 56) note that this form of:

low-intensity pastoralism... [is characterised by] reliance upon semi-natural grasslands and the common need for livestock mobility to overcome spatial and temporal shortages of the forage and fodder provided by this resource.

Changes during the communist period and subsequently made these practices increasingly contentious and difficult to maintain. A recent documentary entitled 'Last Transhumance' shows that only a few tens of shepherd families practice transhumance today in Romania (Lumpan, 2015). Overregulation has placed pressure on transhumant practices and their world has changed continually due to a diminishing of pastoral landscape in post-socialist times and restrictions imposed by private ownership of land (Turnock, 2003).

Processes of decollectivisation and privatisation of rural land following the end of the communist regime in 1989 resulted in the fragmentation of landholdings. Roger (2016: 311) notes that "nearly 4 million small farmers hold fewer than 2 hectares... [while] a few large agribusinesses each hold approximately 50,000 hectares'. Such fragmentation has limited 
This is an Accepted Manuscript of an article published by Taylor \& Francis in Identities on 31 January 2018, available online:

https://www.tandfonline.com/doi/abs/10.1080/1070289X.2017.1400322

opportunities to foster rural economic development despite support from the EU (see Marquardt et al, 2012). Micu (2014: 133) also notes that land has traditionally been understood 'as "means of subsistence" and "social connector" rather than economic asset or means of production.' Where rural development does take place shepherds can find themselves excluded from traditional routes and trails by roads and urban developments (Juler, 2014). Together, these structures and beliefs have impacted the transhumant practices and squeezed the space available, as shepherds are increasingly out of place.

The other challenge faced by shepherds results from attempts to preserve the natural environment and in some areas promote tourism (including hunting). Increasing pressure from the European level to ensure protection of sensitive environments can be translated into restrictions on traditional practices. However, as Catsadorakis (2007) notes, attempts to separate natural and cultural heritage ignore their co-created character. This is supported by research on griffon vultures (Olea and Mateo-Tomás, 2009) and open woodlands in Spain (Carmona et al, 2013). In the Romanian context, Huband et al (2010) note that transhumant practices are relatively low-intensity, have limited environmental impact, having been longestablished. Attempts to monitor animal welfare through registration and concerns over hygiene and the spread of diseases place additional burdens on shepherds (Juler, 2014).

Hunting has a long history in Romania and is regulated by the National Association of Sport Hunters and Fishermen (AGVPS - Asociatia Generala a Vanatorilor si Pescarilor Sportivi din Romania). AGVPS' roots go back to 1870 in Bucharest and gathered over 30,000 hunters during the interwar period (AGVPS, 2017). Romania is a founder since 1930 of International Council of Game and Wildlife Conservation and since 2000 is a member of Federation of Associations for Hunting and Conservation of the EU. ROMSILVA is the Romanian national 
This is an Accepted Manuscript of an article published by Taylor \& Francis in Identities on 31 January 2018, available online:

https://www.tandfonline.com/doi/abs/10.1080/1070289X.2017.1400322

Department of Forestry at the Ministry of Environment, Water and Forests (Ministerul

Mediului, Apelor si Padurilor), which coordinates AGVSP, having local 'ocol silvic' units that regulate hunting seasons and have authority to monitor illegal logging and hunting actions. AGVSP gives permits for rifle for all big game, small game, waterfowl and upland game, with brown bears, wolves, wild boar, chamois and red deer being the most hunted species.

The use of livestock protection dogs (LPDs) has come under greater scrutiny in relation to hunting and lay behind the 2015 protests. Gehring et al (2010) argue that LPDs have traditionally been used to protect stock against bear and wolf attack when in the open. The requirement to protect large carnivores in Europe for conservation and tourism reasons has led to pressure to reduce the use of LPDs, as they are deemed to present a threat. Challenging the idea that they threaten biodiversity, Yilmaz et al (2015) argue that LPDs dissuade large predators from attacking livestock and tend to avoid direct confrontation. Restricting the use of LPDs may instead lead to further problems, as LPDs can become problematic when in close proximity to urban zones as they 'may become inattentive and begin to wander, chase vehicles, harass people, or bark during the night' (Gehring et al, 2010: 305). These pressures further restrict the ability of shepherds to continue their traditional practices and reduce the availability of tools to do so.

It is clear that shepherds in Romania have a latent ability to draw on identity to mobilise and organise as a group. Examining the willingness of farmers in Galicia (Spain) and the Netherlands to engage in protest, Klandermans et al (2002) argue that identification with other farmers is key in determining the likelihood of participation, with participation reinforcing the sense of collective identity. In Romania, the maintenance of traditional 
This is an Accepted Manuscript of an article published by Taylor \& Francis in Identities on 31 January 2018, available online:

https://www.tandfonline.com/doi/abs/10.1080/1070289X.2017.1400322

transhumance practices and the continued importance of LPDs increases identification between shepherds and enables co-ordination. Additionally, the cultural significance of the shepherd (represented by Mioriţa) reinforces the boundary making necessary to sustain an identity, supporting an image of the shepherd in the popular imagination, marked out as distinct from other parts of society. When faced with challenges to their way of life, shepherds therefore have a pre-existing identity to draw on when organising.

The focus of this paper on the 2015 Romanian shepherd protests provides an opportunity to ask how and why a marginalised group can mobilise. As noted above, the position and rights of shepherds have been eroded during the post-communist period, increasing their marginalisation. However, the size and intensity of the protests in December 2015 suggest an ability to draw on identity to resist threats to their way of life. Possessing limited social and economic resources it is argued that as a marginalised group, shepherds have to rely on the limited range of tools at their disposal, primarily around displays of identity that speak to cultural traditions and as such are recognisable to observers.

\section{Methodology}

The research presented in this article draws on a series of interviews with shepherds in western Romania. Participants were identified using a snowball sampling method, beginning with an interview with one shepherd in person who suggested other participants. Interviews were conducted in March 2016 with six shepherds from different counties in the Banat, Oltenia and Transylvania regions, three who participated in the protests and three who did not. The small number of interviews was justified based on the hard to reach nature of the study group and following the suggestion from Guest et al (2006: 78) that it is possible to identify 'high-level, overarching themes' with smaller samples. The interview material was 
This is an Accepted Manuscript of an article published by Taylor \& Francis in Identities on 31 January 2018, available online:

https://www.tandfonline.com/doi/abs/10.1080/1070289X.2017.1400322

used to support and develop concepts and themes emerging from the other primary and secondary sources. The interviews were conducted in Romanian by phone and notes were taken during the interview and written up subsequently (on phone interviews see Sturges and Hanrahan, 2004). Each interview lasted 30-40 minutes and each question was explained in plain language to ensure comprehension. Topics covered included protest targets, connections with protestors in other countries, availability of non-contentious channels, the role of the EU, and previous protest experience.

Invitations for interview were sent to 10 regional branches of the Association of Sheep and Goat Breeders (Asociaţia Crescătorilor de Ovine şi Caprine - ACOC). ACOC is represented at each county unit in Romania through different associations that gather and represent groups of shepherds. The association is responsible for defending shepherds' rights in terms of grazing sheep and goats, selling their products, making them aware of their rights. Only one of the branches was willing to participate and provide written responses to e-mail questions. This information was supplemented by examination of information on the ACOC website and through pronouncements in the media. In addition, the article draws on media sources describing the evolution of the 2015 protests. The Romanian multimedia platform Ziare.com (www.ziare.com) was used to identify slogans and discourses used in the December 2015 events. An investigation of three selected Romanian newspapers (Evenimentul Zilei, Stiri agricole and Adevarul) helped us understand the perception of public opinion on shepherds identity and protests. These sources were complemented by an examination of relevant official documents and laws to develop a clear understanding of the perceived threat to the shepherd's livelihoods.

\section{The 2015 Shepherd Protests}


This is an Accepted Manuscript of an article published by Taylor \& Francis in Identities on 31 January 2018, available online:

\section{https://www.tandfonline.com/doi/abs/10.1080/1070289X.2017.1400322}

The role of protest and contentious actions in Romania has received attention in recent years, with research considering contestation of issues related to the environment (O'Brien, 2009; Vesalon and Creţan, 2013; Creţan, 2015), education (Burean and Badescu, 2014), labour (Varga and Freyberg-Inan, 2015) and austerity (Margarit, 2016). Restrictions on civil society were extensive under the Ceauşescu regime and were slow to loosen subsequently (O'Brien, 2009; Verdery, 1996; Voiculescu and Jucu, 2016). The mobilisation of miners from the Jiu Valley to strike down student protests and attack opposition parties in the early 1990s had a significant dampening effect on the forms of protest that were able to emerge (Gledhill, 2011). Considering the character of post-communist protest Burean and Badescu (2014) point to three periods, during the early transition period $1990-99$ protests by working class groups demanding wages and protection dominated. This was followed by a period of relative quiet with an absence of large-scale protests. In 2012 there was a further shift with the emergence of large-scale protests addressing a 'higher diversity of participants and grievances.... [demanding] a cleaner environment, others requested more democracy and yet others targeted narrower topics such as animal protection, lowering the price of petrol or taxing pensions.' (Burean and Badescu, 2014: 387; see also Margarit, 2016). The shift in form and focus of protest points to changes in the political opportunity structure, as the regime and society consolidated, leading to increased expectations of the state.

Changes experienced in the post-communist agricultural sector and reform of landholding practices have also been examined (see Hartvigsen, 2014; Roger, 2016), but limited consideration has been given to the claims of Romanian agricultural workers. Accession to the EU in 2007 led to a period of adaptation, as farmers were required to change their practices to comply with new regulations coming from the European level. The translation of these pressures continues to be constrained by domestic interests in a situation where civil 
This is an Accepted Manuscript of an article published by Taylor \& Francis in Identities on 31 January 2018, available online:

\section{https://www.tandfonline.com/doi/abs/10.1080/1070289X.2017.1400322}

society and stakeholder involvement are lacking (Stringer and Paalova, 2013). In order to examine more closely the perceptions of agricultural workers in Romania and the ways changes in regulation have impacted practices this section considers the protests involving shepherds attempting to protect their rights. The 2015 mobilisations targeted the national level and were in opposition to changes in hunting laws that sought to challenge traditional practices by reducing the number of dogs a shepherd could use. Although the EU was not a key focus of the protests, pressures from this level to ensure conservation can be seen as underpinning and providing a basis for domestic regulatory change.

The events of December 2015 were highly contentious, involving a large gathering and clashes with police at key sites. The main claim in the protests concerned restrictions on the number of sheepdogs and bans on winter grazing (Mutler, 2015). The Law of Hunting and Hunting Fund Protection (2015) was at the core of the claims. Specifically Article 23/1, which stated:

For the purpose of sustainable management of hunting fauna the following are prohibited

c) livestock grazing in farmland between December 6 and 24 April

k) enabling flocks and herds accompanied by companion dogs whose number exceeds 3 in the mountain area, 2 in the hills and 1 in the plain

While the proposed changes were justified on the sustainability grounds, hunting is a pastime that is traditionally associated with Romania's elite, providing a clear frame for the protesting shepherds. The inequalities faced by sheep breeders were clear in the opinions of the shepherds' leaders' positions. Horatiu Raicu, Secretary-General of Agrostar Foundation, one of the organizers of the 2015 protests, argued (Stiri Agricole, 2015):

with the changes introduced in 2015 there is a novelty, namely that 'the animal farmer can no longer walk on the land'. In particular, we are against Article 23 of Law 149/2015... It is totally abnormal that in a year when agriculture was severely hit by drought, for which no compensation 
This is an Accepted Manuscript of an article published by Taylor \& Francis in Identities on 31 January 2018, available online:

\section{https://www.tandfonline.com/doi/abs/10.1080/1070289X.2017.1400322}

has yet been granted, to promote such a normative act, which only puts a burden on the farmers

and so we decapitalize them.

It was argued that the shepherds saw the proposed changes as a threat to their rights and centuries of traditional practice (Adevarul Financiar, 2015). As such, the 2015 protests were clearly linked to historical divides within society based on identity and status, represented through interpretations of resources and tradition.

The protests on 15 December saw 3000 shepherds from around the country converge at the Izvor Park area in front of the Parliament building in Bucharest. The protest was organized by several animal breeders associations in Romania, in particular by Agrostar and the Association of Breeders and Exporters of Cattle, Sheep and Swine in Romania. Participants were dressed in floor-length sheepskins, blowing horns, brandishing traditional jingle-bells ('talanga') and whistles and displayed banners that said, "You betrayed me for hunting," "Do you want to do something for us? Suspend the law.", "6 December - 23 April, home arrest". They whistled and booed, chanting "Suspend the law" from time to time (Mutler, 2015; Stan, 2015). The major motive was opposition to new regulations enacted in the Hunting Act, which prohibited the establishment, maintenance or harvesting of agricultural crops, without ensuring the protection of the wildlife of hunting and limiting the number of dogs that the animal breeder can use. This is clear in slogans such as 'The dog is upset he was fired' and 'I do not want to watch sheep anymore, just to watch the parliament members'. These slogans sought to highlight the plight of the shepherds, while also attempting to generate support by challenging the effectiveness and legitimacy of the state administration.

The size of the protest meant that riot police were deployed to maintain order and had to use tear gas to quell the protest. After a peaceful protest of about two hours (9-11 a.m.), the shepherds threatened to intensify their actions if politicians failed to address their demands. 
This is an Accepted Manuscript of an article published by Taylor \& Francis in Identities on 31 January 2018, available online:

\section{https://www.tandfonline.com/doi/abs/10.1080/1070289X.2017.1400322}

One protestor stated 'If it is not solved, we will block the streets in Romania. We will come with forks and axes, because that's what our ancestors did and solved the problems.' (Stan, 2015) The intensity of the protest escalated shortly afterwards when 1000 protestors broke through police lines into the Parliament grounds, with several dozen scaling the walls of the parliamentary palace and others forcing their way into the inner courtyard (AFP, 2015). A delegation of protesters entered Parliament in the negotiations at noon. The shepherds were received by the president of the Senate Calin Popescu Tariceanu. An official said, at the end of the talks with the protesters, that he would pass their claims on to PM Dacian Cioloş. The protest ended at 5 p.m., when sheep breeders who were in negotiations with the Chamber of Deputies' Agriculture Commission forwarded to the demonstrators to leave home after they had promised to change the law. Faced with such strong opposition to the new law, the government announced that the two contentious articles would be removed and a revision prepared by April 2016, representing a victory for the shepherds (Associated Press, 2015).

Views expressed by politicians and the public were generally in favour of the shepherds, suggesting recognition of their claims. George Becali, a right wing populist, the leader of Partidul Noua Generatie (The New Generation Party), a Macedo-Romanian coming from a wealthy shepherd family, arguing (Popa, 2015):

To 100 sheep, you have to have one dog, you have to have 20 dogs for 2,000 sheep. You can keep 20 dogs in your household but you are not allowed now to keep them in the house.... They have no idea what they have voted. Lawmakers voted like a sheep. These people (i.e shepherds) love their dogs like their own children, dogs are part of their identity.... Our problem in the country is not the sheep, it's the problem of hunting

Moreover, Liviu Dragnea, the leader of the left wing Partidul Social Democrat (PSD Democrat Social Party) was emotional towards the protesters and asked Romanian President Klaus Iohannis, through an open letter, to resubmit the Hunting Law to Parliament, stating 
This is an Accepted Manuscript of an article published by Taylor \& Francis in Identities on 31 January 2018, available online:

\section{https://www.tandfonline.com/doi/abs/10.1080/1070289X.2017.1400322}

(Stiri Agricole, 2015):

The initiators of the law have virtually taken over the hunter's arguments, namely that too many dogs in the wilds affect wildlife, but also tourism and hunting. Perhaps the number of dogs regulated by this law is a problem - see the proof and protest of the shepherds, but I think it is our duty to analyze their point of view, and if the arguments are solid, we proceed accordingly, because it is obvious that the parliamentary debate was insufficient at the moment of the adoption of these regulations

Success in challenging the law represented a victory and also highlighted recognition and acceptance of their claims among the political class.

Public opinion also appeared to recognise the shepherd claims and support traditional practices, although these views were also tied to Romania's EU membership. An examination of the newspapers Evenimentul Zilei, Stiri agricole and Adevarul over the 15-22 December suggested that public opinion (about 90 per cent) was in favour of maintaining existing practices and accepted the reasoning behind the protests. People were angry over EU's lack of concern regarding the loss of transhumance by limiting shepherds traditional way of life (including using sheepdogs and walking on natural pastures). A minority view expressed in the newspapers was in favour of EU regulations 'which shepherds have to follow as any other ordinary EU citizen' and also argued that shepherds are too wealthy and have enough rights for grazing.

\section{Assuming Identity: Voices of the Shepherds}

The protests of 2015 challenged a specific set of regulations that had the potential to threaten traditional shepherd practices. The frustration that drove the actions is represented in a statement from a shepherd in Caras-Severin County (Interview Ro4) who did not take part in the protests who argued 'I agree they could hunt but leave me to do my job which my 
This is an Accepted Manuscript of an article published by Taylor \& Francis in Identities on 31 January 2018, available online:

\section{https://www.tandfonline.com/doi/abs/10.1080/1070289X.2017.1400322}

forefathers did for hundreds of years.' Considering the views of the shepherds who took part in the protests and those who did not, there is a consistent perspective on the motivations and aims. This common understanding amongst the shepherds points to the existence of an identity, based on shared practices and tradition. Similar to the findings of Klandermans et al (2002) in Spain and the Netherlands, the existence of an association representing the interests of the shepherds was significant in ensuring identity could be mobilised to demonstrate WUNC (Tilly and Wood, 2009) when threatened.

The main targets of the 2015 protests were the politicians who were responsible for the hunting law. The shepherds interviewed questioned the motivations of the politicians, with links with wealthy hunters being raised as an issue of concern. A participant from Gorj County (Interview Ro2) stated 'I don't like that most of the hunters are rich people who are in good relation to the parliament members...' Others echoed this point, noting that the hunters were as much to blame as the politicians. This suggests a relatively closed political system and coherent elite block, making contentious actions a viable alternative (Tilly, 2008). A central grievance that drove the protests was the loss of income and access that resulted from the change in the law. The lack of consideration to what happens to the shepherds and their livelihood with participants arguing that the 'animals need to move' (Interview Ro2) and 'I paid a lot of money in advance to the landowner of the pastures where my sheepflock move' (Interview Ro3). These statements illustrate processes of boundary activation, as the shepherds reinforce their identity in opposition to the hunters and politicians threatening their way of life.

The shepherds expressed mixed views about the role and impact of the EU, as the main focus was the national level. Participants argued that the EU does not respect tradition, with a 
This is an Accepted Manuscript of an article published by Taylor \& Francis in Identities on 31 January 2018, available online:

https://www.tandfonline.com/doi/abs/10.1080/1070289X.2017.1400322

shepherd from Gorj County (Interview Ro2) claiming 'the EU push pressure on us to respect

their laws... They want to destroy transhumance because it is an old habit.' This perception that the EU wanted to standardise practices regardless of cultural and historical traditions was common. The point was made that such requirements remove opportunities for new sources of income, such as heritage tourism (Interview Ro4). However, it was noted that implementation of regulations by the Romanian authorities in these areas is done poorly (Interview Ro5) or in a disingenuous manner to cover local interests (Interview Ro1). Although the EU was seen as a driver, the participants did not suggest awareness of similar protests or dissatisfaction in other European states, suggesting limited organising and networking among shepherds at higher levels, making the protests more opportunistic. In this regard, Tilly (2003: 131) argues:

The mechanisms generating opportunism concentrate on activating previously available boundaries, stories, and social relations more than incorporating multiple social sites into coordinated actions.

As a recent entrant to the field, the EU is not embedded in existing stories and social relations to the same extent, making it a less obvious target or source of potential resources and allies.

The costs and risks associated with protest, especially those such as the 2015 events where riot police and tear gas were deployed, suggest other non-contentious channels were not sufficient to challenge the hunting law. Asked whether they had attempted to use regular channels some of the participants mentioned the Agency for Payments and Intervention in Agriculture (Agenţia de Plăţi şi Intervenţie pentru Agricultură - APIA) and the Funding Agency for Rural Investment (Agenţia pentru Finanţarea Investiţiilor Rurale - AFIR), to little effect. One shepherd who had not contacted these organisations stated 'we, the shepherds, are very united. If we hear of limiting our rules and rights then we have to protest.' (Interview 
This is an Accepted Manuscript of an article published by Taylor \& Francis in Identities on 31 January 2018, available online:

\section{https://www.tandfonline.com/doi/abs/10.1080/1070289X.2017.1400322}

Ro2) These attitudes suggest that the influence and usefulness of official representative bodies is seen as limited, with one participant grouping their leaders alongside members of Parliament and the President in being responsible (Interview Ro4). Reliance on tradition and identity is key to the shepherds and provided a mechanism through which they could organise and mobilise. As noted, culture and tradition are powerful forces, potentially enabling the establishment of thick trust networks that preclude the acceptance of outsiders (see Lagerspetz, 2001).

Looking back to previous protests and the period under the Ceauşescu regime before 1989 the current threats to tradition are clearly articulated. Reflecting on protests in 2009 over regulations on packaging and hygiene of agricultural products (Associated Press, 2009), the shepherds noted that they failed to achieve anything. The point was made that the regulations had been harmful to the traditional practices, making it harder to sell products directly (similar to Roseman (2004)). The participant from Valcea County (Interview Ro6) argued 'All our products were natural; now they have to put chemical conservants in large stores in order to maintain their taste.' It was also noted that at the time there was a perception that laws from Brussels could not be challenged (Interview Ro4). With regard to the Ceauşescu period, participants argued that life was hard, but the laws changed less frequently (Interview Ro3). The shepherds noted that regulations were looser and the absence of private ownership made the continuation of traditional practices such as transhumance easier to maintain (Interviews Ro2, Ro5, and Ro6). The absence of free spaces (Johnson, 2011) limited dissent and led to stable social relations, generating certainty for groups reliant on traditional practices, such as shepherds.

The views of shepherds regarding traditional practices were echoed by a representative of 
This is an Accepted Manuscript of an article published by Taylor \& Francis in Identities on 31 January 2018, available online:

https://www.tandfonline.com/doi/abs/10.1080/1070289X.2017.1400322

ACOC, who noted that a representative in Bihor County launched a petition against the Romanian Ministry of Agriculture's National Authority for Veterinary Health and Food Safety (Autoritatea Naţională Sanitară Vetarinară şi pentru Siguranţa Alimentelor ANSVSA) in 2014 (Interview Ro7). An important claim was that the breed of sheep raised in Romania (Turcana) is suited to transhumant practices and that these in turn support biodiversity due to their long history. Building on the views of the shepherds, it was argued that the state needed to do more to support traditional practices of transhumance and the production of livestock products. With regard to the role of the EU, it was noted that ACOC was in contact with farmers in the UK, Germany, France and Spain and that these contacts suggested that farmers were compensated for disruption caused by hunting. While there was contact, there was no mention of co-ordinated activity in response to the EU regulations, suggesting that these issues remain rooted at the national level (Interview Ro7). As the representative of shepherds and breeders, ACOC has attempted to advance their claims, but has been faced with an unreceptive ANSVSA.

Considering the range of views expressed in the interviews it is clear that tradition features strongly in their concerns. Although the participant from Sibiu County (Interview Ro3) argued that threats to livelihood are the only things capable of mobilising shepherds, there was a shared perception of recent events. Failure of government regulation and EU attempts to standardise practices were perceived as threats to established ways of life, even if they did not lead to more frequent mobilisations. Several participants noted that the privatisation of land and attempts by the government to more closely control shepherd practices presented a threat to the continued viability of transhumance. Reference to forefathers and how they managed the land appeared throughout the interviews, reinforcing the strength of traditional practices in identity formation. Comparing the period under Ceauşescu with the 
This is an Accepted Manuscript of an article published by Taylor \& Francis in Identities on 31 January 2018, available online:

https://www.tandfonline.com/doi/abs/10.1080/1070289X.2017.1400322

contemporary situation, there is a sense that under the former regime they were more able to get on with their traditional way of life. One factor that was mentioned by the participant from Sibiu County (Interview Ro3) alone was that arguments around biodiversity were being used falsely to challenge existing practices as 'our sheep are for thousands of years part of the landscape.' This perception echoes the argument made by Catsadorakis (2007) regarding the co-creation of natural and cultural heritage, suggesting that conservation was being prioritised over the preservation of traditional lifestyles.

The shepherd protests took place during a period of heightened activity in Romania, as largescale actions forced changes in government. This pattern of protest was also seen in other countries in the region, as the effects of the global financial crisis and Eurozone crisis challenged the ability of the EU to provide the promised benefits of membership (Beissinger and Sasse, 2012). The shepherd protests share similarities with the wider patterns of mobilisation, as they seek to react to perceived change that benefits others while harming or failing to advance their particular interests. The mobilisations were facilitated by the sense of identity that was derived from the standing of shepherds, occupying an established position in the national imaginary that enabled them to reinforce boundaries while also appealing to outside observers for recognition of their claims.

\section{Conclusion}

Although the shepherd is an economically marginal figure in Romania, long association with folk history and the cultural identity of the country provides a degree of legitimacy and recognition of their claims. Changes wrought by processes of democratisation and privatisation have challenged traditional practices and led to further economic marginalisation (Juler, 2014; Roger, 2016). Fragmentation of land tenure has for example 
This is an Accepted Manuscript of an article published by Taylor \& Francis in Identities on 31 January 2018, available online:

https://www.tandfonline.com/doi/abs/10.1080/1070289X.2017.1400322

made transhumant practices more difficult and costly, as access must be negotiated with multiple private landholders. The mobilisation of 2015 represented an attempt to resist the further erosion of rights possessed by shepherds. The geographically dispersed and marginalised position of shepherds has made such actions infrequent, but the sense of shared identity means that the actions had something to bind participants and represent a wider community. Changes driven by the EU and the Romanian state were recognised as direct threats to the interests and livelihood of shepherds, providing the impetus to act. In presenting their claims, the shepherds drew on symbols that were culturally resonant in order to generate wider support and legitimacy for their actions.

On a broader scale, the protests raised questions regarding the interaction between natural and cultural heritage. Increasing pressure to conserve the natural environment has been embedded within European governance and has translated through to domestic policy-making. In Romania, the limited scope for civil society participation has led to a situation where regulations are introduced with limited consideration for the groups impacted. The shepherd protests occurred during a period of heightened contention in Romania, drawing on a common identity in order to enable mobilisation. Their success shows the way in which marginalised groups can draw on recognisable symbols to represent and channel perceived failings in the operation of the state. 
This is an Accepted Manuscript of an article published by Taylor \& Francis in Identities on 31 January 2018, available online:

https://www.tandfonline.com/doi/abs/10.1080/1070289X.2017.1400322

References:

Agence France-Presse. 2015. “Thousands of Angry Shepherds Storm Romanian

Parliament." 15 December 2015.

AGVPS. 2017. "Istoricul AGVPS.” http://agvps.ro/despre/istoricul-agvps-2/ Accessed 22 July 2017

Aldrich, H. and J. Pfeffer. 1976. "Environments of Organizations.” Annual Review of Sociology 2: 79-105.

Associated Press. 2009. "Romanian Shepherds Protest New EU Regulations.” 12

February http://www.romanianewswatch.com/2009/02/romanian-shepherds-protestnew-eu.html. Accessed 5 February 2016.

Associated Press. 2015. "Romania: Government Removes Sheepdog Restrictions.” 16 December.

Beissinger, M. and G. Sasse. 2012. "An End to "Patience"? The Great Recession and Economic Protest in Eastern Europe.” Oxford: Nuffield Working Paper Series in Politics.

https://www.nuffield.ox.ac.uk/politics/papers/2012/Beissinger_and_Sasse_working_pap er_2012_01.pdf Accessed 13 August 2015.

Buechler, H. and J. Buechler. 2000. "Farmers, Conflict, and Identity in Eastern Germany.” Identities 7 (1): 39-83. doi: 10.1080/107289X.2000.9962659 
This is an Accepted Manuscript of an article published by Taylor \& Francis in Identities on 31 January 2018, available online:

https://www.tandfonline.com/doi/abs/10.1080/1070289X.2017.1400322

Burean, T. and G. Badescu. 2014. "Voices of Discontent: Student Protest Participation in Romania.” Communist and Post-Communist Studies 47 (3-4): 385-397. doi:

10.1016/j.postcomstud.2014.10.004

Buzea, C. and F. Scâneri. 2011. "Occupational Prestige in Romania - An Exploratory

Study." Bulletin of the Transilvania University of Braşov 4, no. 1: 9-18.

http://but.unitbv.ro/Bulletin/Series\%20VII/BULETIN\%20VII\%20PDF/03\%20buzea\%2

0scarneci\%201\%20BUT\%202011.pdf Accessed 4 April 2016.

Carmona, C., F. Azcárate., E. Oteros-Rozas., J. González., and B. Peco. 2013.

"Assessing the Effects of Seasonal Grazing on Holm Oak Regeneration: Implications for the Conservation of Mediterranean Dehesas." Biological Conservation 159: 240247. doi: 10.1016/j.biocon.2012.11.015

Catsadorakis, G. 2007. "The Conservation of Natural and Cultural Heritage in Europe and the Mediterranean: A Gordian Knot?" International Journal of Heritage Studies 13 (4-5): 308-320. doi: 10.1080/13527250701350850

Chandhoke, N. 2001. “The 'Civil' and the 'Political' in Civil Society.” Democratization 8 (2): 1-24. doi: 10.1080/714000194

Constantin, M. 2005. "Capitalism and Transhumance: A Comparison of Three Pastoral Market Types in Europe 1950-2000." New Europe College Yearbook 2003-2004. Bucharest: New Europe College. 
This is an Accepted Manuscript of an article published by Taylor \& Francis in Identities on 31 January 2018, available online:

https://www.tandfonline.com/doi/abs/10.1080/1070289X.2017.1400322

Cretan, R. 2015. “Mapping Protests against Dog Culling in Post-Communist Romania.” Area 47 (2): 155-165. doi:10.1111/area.12155.

Evenimentul Zilei (2015) Ciobanii iau cu asalt PalatulParlamentului (Shepherds assault the Parliament) 16 December 2015 http://evz.ro/ciobanii-iau-cu-asalt-palatulparlamentului-afla-motivul-nemultumirii-lor.html, Accessed 17 June 2017

Gehring, T., K. VerCauteren and J. Landry. 2010. "Livestock Protection Dogs in the $21^{\text {st }}$ Century: Is an Ancient Tool Relevant to Modern Conservation Challenges?” BioScience 60 (4): 299-308.

Gledhill, J. 2011. “Three Days in Bucharest: Making Sense of Romania's Transitional Violence, 20 Years On.” Europe-Asia Studies 63 (9): 1639-1669. doi: $10.1080 / 09668136.2011 .611652$

Goldstone, J. and C. Tilly. 2001. "Threat (and Opportunity): Popular Action and State Response in the Dynamics of Contentious Action.” In Silence and Voice in the Study of Contentious Politics, edited by R. Aminzade, J. Goldstone, D. McAdam, E. Perry, W. Sewell, S. Tarrow, and C. Tilly, 51-88. Cambridge: Cambridge University Press.

Guest, G., Bunce, A. and Johnson, L. 2006. "How Many Interviews are Enough? An Experiment with Data Saturation and Variability.” Field Methods 18(6): 59-82. 
This is an Accepted Manuscript of an article published by Taylor \& Francis in Identities on 31 January 2018, available online:

\section{https://www.tandfonline.com/doi/abs/10.1080/1070289X.2017.1400322}

Hartvigsen, M. 2014. "Land Reform and Land Fragmentation in Central and Eastern

Europe." Land Use Policy 36: 330-341. doi: 10.1016/j.landusepol.2013.08.016

Huband, S., D. McCracken. and A. Mertens. 2010. "Long and Short-Distance

Transhumant Pastoralism in Romania: Past and Present Drivers of Change.”

Pastoralism 1 (1): 55-71.

Hunt, S. and R. Benford. 2004. "Collective Identity, Solidarity, and Commitment.” In

The Blackwell Companion to Social Movements, edited by D. Snow, S. Soule, and H.

Kriesi, 433-457. Oxford: Blackwell Publishing.

Johnston, H. 2011. States and social movements. Cambridge: Polity.

Juler, C. 2014. "După Coada Oilor: Long-Distance Transhumance and its Survival in Romania." Pastoralism: Research, Policy and Practice 4 (4): 1-17. doi: 10.1186/20417136-4-4

Kideckel, D. 2004. "Miners and Wives in Romania’s Jiu Valley: Perspectives on Postsocialist Class, Gender, and Social Change.” Identities 11 (1): 39-63. doi: $10.1080 / 725289024$

Klandermans, B. 2004. “The Demand and Supply of Participation: Social-Psychological Correlates of Participation in Social Movements." In The Blackwell Companion to Social Movements, edited by D. Snow, S. Soule, and H. Kriesi, 360-379. Oxford: Blackwell Publishing. 
This is an Accepted Manuscript of an article published by Taylor \& Francis in Identities on 31 January 2018, available online:

https://www.tandfonline.com/doi/abs/10.1080/1070289X.2017.1400322

Klandermans, B., J. Sabucedo, M. Rodriguez, and M. de Weerd. 2002. "Identity

Processes in Collective Action Participation: Farmers' Identity and Farmers' Protest in the Netherlands and Spain.” Political Psychology 23 (2): 235-251. doi: 10.1111/0162895X.00280/

Lumpan, D 2015. "Ultima transhumanta." [The Last Transhumance] Retrived 22 July from https://www.roevents.ro/ultima-transhumanta-un-proiect-de-dragos-lumpan-setransforma-intr-un-film-documentar.html Accessed 22 July 2017.

Margarit, D. 2016. "Civic Disenchantment and Political Distress: The Case of the Romanian Autumn.” East European Politics 32 (1): 46-62. doi:

$10.1080 / 21599165.2015 .1129945$

Marquardt, D., J. Möllers, and G. Buchenrieder. 2012. “Social Networks and Rural Development: LEADER in Romania.” Sociologia Ruralis 52 (4): 398-431. doi: 10.1111/j.1467-9523.2012.00571.x/

Micu, C. 2014. "Social Structure and Land Property in Romanian Villages (19191989)." Martor, 19: 133-148.

Mutler, A. 2015. "Romanian Riot Police Fire Tear Gas at Protesting Shepherds." Associated Press 15 December. 
This is an Accepted Manuscript of an article published by Taylor \& Francis in Identities on 31 January 2018, available online:

https://www.tandfonline.com/doi/abs/10.1080/1070289X.2017.1400322

O’Brien, T. 2009. "Shifting Views of Environmental NGOs in Spain and Romania."

Southeast European and Black Sea Studies 9 (1-2): 143-160.

doi:10.1080/14683850902723462.

Olea, P., and P. Mateo-Tomás. 2009. “The Role of Traditional Farming Practices in Ecosystem Conservation: The Case of Transhumance and Vultures." Biological Conservation 142 (8): 1844-1853. doi: 10.1016/j.biocon.2009.03.024

Popa, C. 2015. Gigi Becali se implica in protestul ciobanilor (Becali takes action in the shephers protests), EvenimentulZilei, 15 December 2015, http://evz.ro/gigi-becali-seimplica-in-protestul-ciobanilor-parlamentarii-h-abar-nu-au-ce-lege-s-a-adoptat-au-votatca-oile.html Accessed 17 June 2017

Roger, A. 2016. "Power in the Field: Explaining the Legitimisation of Large-Scale Farming in Romania.” Sociologia Ruralis 56 (2): 311-328. doi: 10.1111/soru.12087

Roseman, S. 2004. "Bioregulation and Comida Caseira in Rural Galicia, Spain." Identities 11 (1): 9-37. doi: 10.1080/725289017

Salvatori, V., H. Okarma, O. Ionescu, Y. Dovhanych, S. Find'o, and L. Boitani. 2002. "Hunting Legislation in the Carpathian Mountains: Implications for the Conservation and Management of Large Carnivores.” Wildlife Biology 8 (1): 3-10.

Shirasaka, S. 2007. "The Transhumance of Sheep in the Southern Carpathian Mountains, Romania.” Geographical Review of Japan 80(5): 94-115. 
This is an Accepted Manuscript of an article published by Taylor \& Francis in Identities on 31 January 2018, available online:

https://www.tandfonline.com/doi/abs/10.1080/1070289X.2017.1400322

Stan, F. 2015. "Mii de Ciobani au Protestat la Parlament." [Thousands of shepherds protested at the Parliament], 15 December. http://www.romaniatv.net/revolta-in-randulciobanilor-peste-3-000-de-crescatori-de-oi-vin-sa-protesteze-in-capitala_262934.html Accessed 22 July 2017

Stiri agricole. 2015. Peste 4000 de oieri protesteaza in capital (Over 3000 shepgerd protest in the capital city), 15 December https://www.stiriagricole.ro/peste-3-000-deoieri-protesteaza-astazi-in-capitala-care-sunt-nemultumirile-crescatorilor-de-ovine32436.html Accessed 17 June 2017

Stringer, L. and J. Paavola. 2013. "Participation in Environmental Conservation and Protected Area Management in Romania: A Review of Three Case Studies.” Environmental Conservation 40 (2): 138-146. doi: 10.1017/S0376892913000039

Sturges, J. and K. Hanrahan. 2004. “Comparing Telephone and Face-to-Face Qualitative Interviewing: A Research Note.” Qualitative Research 4(1): 107-18.

Tarrow, S. 2011. Power in movement: Social movements and contentious politics $3^{\text {rd }}$ ed. Cambridge: Cambridge University Press.

Tilly, C. 2003. The politics of collective violence. Cambridge: Cambridge University Press.

Tilly, C. 2008. Contentious performances. Cambridge: Cambridge University Press. 
This is an Accepted Manuscript of an article published by Taylor \& Francis in Identities on 31 January 2018, available online:

https://www.tandfonline.com/doi/abs/10.1080/1070289X.2017.1400322

Tilly, C. and S. Tarrow. 2007. Contentious politics. Boulder: Paradigm Press.

Tilly, C. and L. Wood. 2009. Social movements, 1768-2008 $2^{\text {nd }}$ ed. Boulder: Paradigm Publishers.

Varga, M. and A. Freyberg-Inan. 2015. "Post-Communist State Measures to Thwart Organized Labor: The Case of Romania.” Economic and Industrial Democracy 36 (4): 677-699. doi: 10.1177/0143831X14548770

Verdery, K. 1996. What was socialism and what comes next?. Princeton: Princeton University Press.

Vesalon, L., and R. Cretan. 2013. "Mono-Industrialism and the Struggle for Alternative Development: The Case of the Rosia Montana Project." Tijdschrift Voor Economische En Social Geografie 104 (5): 539-555. doi:10.1111/tesg.12035.

Voiculescu S. and I. S. Jucu 2016. "Producing Urban Industrial Derelict Places: The Case of the Solventul Petrochemical Plant in Timisoara." European Urban and Regional Studies 23 (4): 765-781.

Vuia, R. 1964. Tipuri de Păstorit la Români. Bucharest: Editura Academiei RSR.

Wald, N. 2013. "Bridging Identity Divides in Current Rural Social Mobilisation." Identities 20 (5): 598-615. doi: 10.1080/1070289X.2013.819001 
This is an Accepted Manuscript of an article published by Taylor \& Francis in Identities on 31 January 2018, available online:

https://www.tandfonline.com/doi/abs/10.1080/1070289X.2017.1400322

Yilmaz, O., Y. Ertürk., F. Coşkun. and M. Ertuğrul. 2015. “Using Livestock Guardian Dogs in the Balkans." Agriculture and Forestry 61 (1): 161-173.

\section{Interviews:}

2015 Protest Participant

Ro1 - Sacele, Braşov County, Transylvania, 21 March 2016 - phone interview.

Ro2 - Tismana, Gorj County, Oltenia, 22 March 2016 - phone interview.

Ro3 - Jina, Sibiu County, Transylvania, 22 March 2016 - phone interview.

2015 Protest Non-Participant

Ro4 - Vermes, Caras-Severin County, Banat, 20 March 2016 - in person and phone interview.

Ro5 - Rameti, Alba County, Transylvania, 21 March, 2016 - phone interview.

Ro6 - Vaideeni, Valcea County, Oltenia, 22 March 2016 - phone interview.

Ro7 - ACOC Păstorul, Bihor County, Crișana, 29 March, 2016 - e-mail

correspondence. 